\title{
Enthalpies of Precipitation of Silver Halides; Entropy of the Aqueous Silver lon
}

\author{
Donald D. Wagman and Marthada V. Kilday \\ Institute for Materials Research, National Bureau of Standards, Washington, D.C. 20234
}

(May 25, 1973)

\begin{abstract}
The enthalpies of precipitation of silver halides and the enthalpies of solution of $\mathrm{AgNO}_{3}, \mathrm{KCl}$, and $\mathrm{KBr}$ in $\mathrm{H}_{2} \mathrm{O}$ were measured in an adiabatic solution calorimeter.

From the enthalpy measurements of $\mathrm{KCl}(\mathrm{c})$ and $\mathrm{KBr}(\mathrm{c})$ in $\mathrm{AgNO}_{3}(\mathrm{aq})$, and of $\mathrm{AgNO}_{3}(\mathrm{c})$ in $\mathrm{KCl}(\mathrm{aq})$, in $\mathrm{KBr}(\mathrm{aq})$, and in $\mathrm{KI}(\mathrm{aq})$, we calculated (in $\mathrm{kJ} \cdot \mathrm{mol}^{-1}$ ) $-65.724,-84.826$, and -111.124 for $\Delta H^{\circ}$ $\operatorname{pptn}(298.15 \mathrm{~K})$ for the averages of the chloride, bromide, and iodide reactions, respectively.

A reevaluation of the data for the enthalpy of solution of $\mathrm{AgNO}_{3}(\mathrm{c})$ has resulted in our selected best value,

$$
\begin{aligned}
\Delta H^{\circ}(\infty)(298.15 \mathrm{~K}) & =22.730+0.084 \mathrm{~kJ} \cdot \mathrm{mol}^{-1} \\
& =5.433 \pm 0.020 \mathrm{kcal} \cdot \mathrm{mol}^{-1}
\end{aligned}
$$
\end{abstract}

A table of enthalpies of dilution of $\mathrm{AgNO}_{3}(\mathrm{aq})$ is also given.

The average standard entropy for the aqueous silver ion at $298.15 \mathrm{~K}$ is found to be

$$
\begin{aligned}
S^{\circ}\left[\mathrm{Ag}^{+}(\mathrm{aq})\right] & =73.42 \pm 0.20 \mathrm{~J} \cdot \mathrm{mol}^{-1} \cdot \mathrm{K}^{-1} \\
& =17.55 \pm 0.05 \mathrm{cal} \cdot \mathrm{mol}^{-1} \cdot \mathrm{K}^{-1}
\end{aligned}
$$

Key words: $\mathrm{AgBr} ; \mathrm{AgCl} ; \mathrm{AgI} ; \mathrm{AgNO}_{3}$; enthalpy of dilution; enthalpy of precipitation; enthalpy of solution; entropy; heat of reaction; $\mathrm{KBr}$; $\mathrm{KCl}$; solution calorimetry; thermochemistry.

\section{Introduction}

The thermodynamic properties of the silver halides, $\mathrm{AgCl}, \mathrm{AgBr}$, and $\mathrm{AgI}$, are extremely important quantities in determining the properties of many other substances. In conjunction with metallic silver they form electrochemical half-cells of high reproducibility. These half-cells have been combined with many other electrodes to yield thermodynamic data of high precision for a number of chemical reactions. In particular, these electrodes have been combined with the corresponding half-cells containing the aqueous halogen acids and salts to determine the activities of the acids and salts at various temperatures $[1] ;{ }^{1}$ these acids are in turn the keystones for the establishment of a self-consistent set of tables of enthalpies and Gibbs energies of formation [2]. However, the final verification of electrochemical data must come from other sources. To quote from Harned and Owen [3]:

“. . . Cell reactions, no matter how simple and obvious, must be treated as hypothetical until it can be shown that thermodynamic quantities calculated from

\footnotetext{
${ }^{1}$ Figures in brackets indicate literature references at the end of this paper.
}

the electromotive force, $\Delta F, \Delta H$, equilibrium constants, etc., have been checked by other evidence."

In the course of our reevaluation of the thermodynamic data on silver and silver compounds, we compared the electrochemical data on the silver-silver halide systems for the reaction $\mathrm{Ag}^{+}(\mathrm{aq})+\mathrm{X}^{-}(\mathrm{aq}) \rightarrow$ $\operatorname{AgX}(\mathrm{c})\left[\mathrm{X} \equiv \mathrm{Cl}^{-}, \mathrm{Br}^{-}, \mathrm{I}^{-}\right]$with the available calorimetric measurements for the reactions. For this comparison we reextrapolated the EMF measurements of Owen and Brinkley [4] using more recent values [45] for the various fundamental constants and converting to absolute electrical units. These results were then combined with the cell data for the silver-silver halide electrodes [1] to calculate the enthalpies of the precipitation reactions. The summary comparison is shown in table 1 . Because of the scatter in the various calorimetric measurements we decided to redetermine the enthalpies of precipitation of the three silver halides and establish more precisely the thermodynamic validity of the EMF data for these systems. The reaction scheme used is as follows:

$$
\begin{aligned}
\mathrm{AgNO}_{3}(\mathrm{c})+\mathrm{KX}(\infty) & \longrightarrow \mathrm{AgX}_{(\mathrm{K})}+\mathrm{KN} \mathrm{O}_{3}(\infty) ; \Delta H_{1} \\
\mathrm{AgNO}_{3}(\mathrm{c}) & \longrightarrow \mathrm{AgNO}_{3}(\infty) ; \Delta H_{2}
\end{aligned}
$$

$\mathrm{AgNO}_{3}(\infty)+\mathrm{KX}(\infty) \longrightarrow \mathrm{AgX}(\mathrm{c})+\mathrm{KNO}_{3}(\infty) ; \Delta H_{1}-\Delta H_{2}$ 
TABLE 1. Comparison of data for the enthalpy of precipitation of the silver halides obtained from various methods

\begin{tabular}{|c|c|c|c|}
\hline Authors and year & Method & $-\Delta H^{\circ}(298.15 \mathrm{~K})^{a}$ & Reference \\
\hline & & $k J \cdot \mathrm{mol}^{-1}$ & \\
\hline \multicolumn{4}{|l|}{$\mathrm{Ag}^{+}+\mathrm{Cl}^{-} \rightarrow \mathrm{AgCl}(\mathrm{c}):$} \\
\hline Lange and Fuoss (1927).. & Calorimetric......... & 65.710 & [5] \\
\hline Thomsen $(1883) \ldots \ldots \ldots \ldots \ldots$ & ......do.............. & 64.98 & {$[6]$} \\
\hline Owen and Brinkley (1938) ${ }^{\mathrm{b}}$. & $\mathrm{EMF} \ldots \ldots \ldots$ & 65.642 & [4] \\
\hline Gledhill and Malan (1954)..... & Solubility......... & 66.78 & {$[13]$} \\
\hline \multicolumn{4}{|l|}{$\mathrm{Ag}^{+}+\mathrm{Br}^{-} \rightarrow \mathrm{AgBr}(\mathrm{c}):$} \\
\hline Berthelot $(1881) \ldots \ldots \ldots \ldots \ldots . . .$. & Calorimetric... & 84.1 & [7] \\
\hline Gellner and Skinner (1949)... & $\ldots$ do ........... & 84.9 & [8] \\
\hline Roth $(1944) \ldots \ldots \ldots \ldots \ldots \ldots \ldots$ & ...... do ............. & 90.58 & [9] \\
\hline Thomsen $(1883) \ldots \ldots \ldots \ldots \ldots . . . .$. & ...... do ............ & 82.84 & [6] \\
\hline Owen and Brinkley $(1938)^{b} \ldots \ldots$. & EMF ............. & 84.655 & {$[4]$} \\
\hline Gledhill and Malan (1954) .......... & Solubility............. & 85.56 & {$[13]$} \\
\hline \multicolumn{4}{|l|}{$\mathrm{Ag}^{+}+\mathrm{I}^{-} \rightarrow \operatorname{AgI}(\mathrm{c}):$} \\
\hline Gellner and Skinner (1949)...... & Calorimetric......... & 109.9 & {$[8]$} \\
\hline Berthelot $(1875) \ldots \ldots \ldots \ldots \ldots \ldots$ & ..... do ................. & 110.96 & {$[10]$} \\
\hline Berthelot $(1881) \ldots \ldots \ldots \ldots \ldots \ldots \ldots$ & ......do.................... & 110.08 & [7] \\
\hline Lange and Shibata $(1930) \ldots \ldots \ldots . . . .$. & ..... do ............... & 111.50 & [11] \\
\hline Yatsimirskii and Skutov (1954).... & ..... do ............... & 105.18 & [12] \\
\hline Thomsen $(1883)$.................... & ........do do ....................... & 109.37 & [6] \\
\hline Owen and Brinkley $(1938)^{b} \ldots \ldots . .$. & EMF $\ldots \ldots \ldots \ldots \ldots \ldots \ldots$ & 111.01 & {$[4]$} \\
\hline
\end{tabular}

${ }^{a}$ All calorimetric experimental data have been converted to conditions of infinite dilution at $298.15 \mathrm{~K}$ using necessary data from Parker [14]; 1 calorie $=4,1840$ joules.

${ }^{b}$ Recalculated; see text.

In addition, for both chloride and bromide, we used the reciprocal scheme:

$$
\begin{aligned}
\mathrm{KX}(\mathrm{c})+\mathrm{AgNO}_{3}(\infty) & \longrightarrow \mathrm{AgX}(\mathrm{c})+\mathrm{KNO}_{3}(\infty) ; \Delta H_{1}^{\prime} \\
\mathrm{KX}(\mathrm{c}) & \mathrm{KX}(\infty) ; \Delta H_{2}^{\prime}
\end{aligned}
$$

$\mathrm{KX}(\infty)+\mathrm{AgNO}_{3}(\infty) \longrightarrow \mathrm{AgX}(\mathrm{c})+\mathrm{KNO}_{3}(\infty) ; \Delta H_{1}^{\prime}-\Delta H_{2}^{\prime}$

\section{Apparatus and Procedures}

The vacuum-jacketed adiabatic solution calorimeter used in this work has been described in detail [15]. All parts of the calorimeter in contact with the calorimetric solutions are of platinum-iridium alloys or polytetrafluoroethylene (PTFE). The platinum sample holder shown in figure 1 has three interchangeable cylinders; the largest cylinder (volume, $2.7 \mathrm{~cm}^{3}$ ) was used for the crystalline potassium halide samples and a smaller cylinder (volume, $1.9 \mathrm{~cm}^{3}$ ), for the crystalline silver nitrate samples. The calorimetric solutions were approximately $300 \mathrm{~cm}^{3}$ in volume.

The calorimeter temperatures were measured with a $25-\Omega$ platinum resistance thermometer on which one kelvin is $0.10104 \Omega$ at $298.15 \mathrm{~K}$, or with a quartzoscillator thermometer calibrated by comparison with the platinum resistance thermometer (see [15] for calibration data on these thermometers). The last certified calibrations on the standard resistors and the standard cell were made in June and July 1969, respectively. Dial corrections are based on our calibra- tions of the six-dial potentiometer in January 1969 , and of the G-3 Mueller-type resistance bridge, in November 1970. The previous history of this equipment indicates that no significant drift occurred subsequent to these calibrations.

For the experiments reported in sections 3, 4, and 5 , the analytical reagent grade (ACS certified) salts, $\mathrm{KCl}, \mathrm{KBr}$, KI, and $\mathrm{AgNO}_{3}$ were used for the crystalline samples and for the aqueous solutions. The reagents were not dried nor further purified. The weight loss on drying the $\mathrm{AgNO}_{3}$ indicated less than 0.01 percent moisture content.

The 1969 atomic weights [16] were used to calculate the following molar masses: $\mathrm{AgNO}_{3}, 169.8729$; $\mathrm{KCl}, 74.555 ; \mathrm{KBr}, 119.006$; $\mathrm{KI}, 166.0065$; and $\mathrm{H}_{2} \mathrm{O}$, 18.0154. For energy conversions, 1 thermochemical calorie $=4.1840$ joules.

To obtain the buoyancy factors for calculating the mass of the crystalline samples, the following densities (in $\mathrm{g} \cdot \mathrm{cm}^{-3}$ ) were used: $\mathrm{KCl}, 1.988 ; \mathrm{KBr}, 2.75$; and $\mathrm{AgNO}_{3}, 4.352$ [17a]. For the average conditions in this laboratory, the density of air was $0.00118 \mathrm{~g} \cdot \mathrm{cm}^{-3}$. The densities (in $\mathrm{g} \cdot \mathrm{cm}^{-3}$ ) at $296 \mathrm{~K}$ of the aqueous solutions of the salts were taken [17b] as follows: $\mathrm{KCl}(0.75$ wt. \%), 1.0013; $\mathrm{KBr}(1.19$ wt. \%), 1.0061; KI (1.67 wt. \%), 1.0100; $\mathrm{AgNO}_{3}$ Stock Soln. No. 1 (2.55 wt. \%), 1.0194; and $\mathrm{AgNO}_{3}$ Stock Soln. No. 2 (2.48 wt. \%) and $\mathrm{AgNO}_{3}$ Stock Soln. No. 3 (2.49 wt. \%), 1.0188. Each stock solution was initially $2 \mathrm{dm}^{3}$ in volume and was stored in polyethylene bottles in a dark cabinet when not in use. 


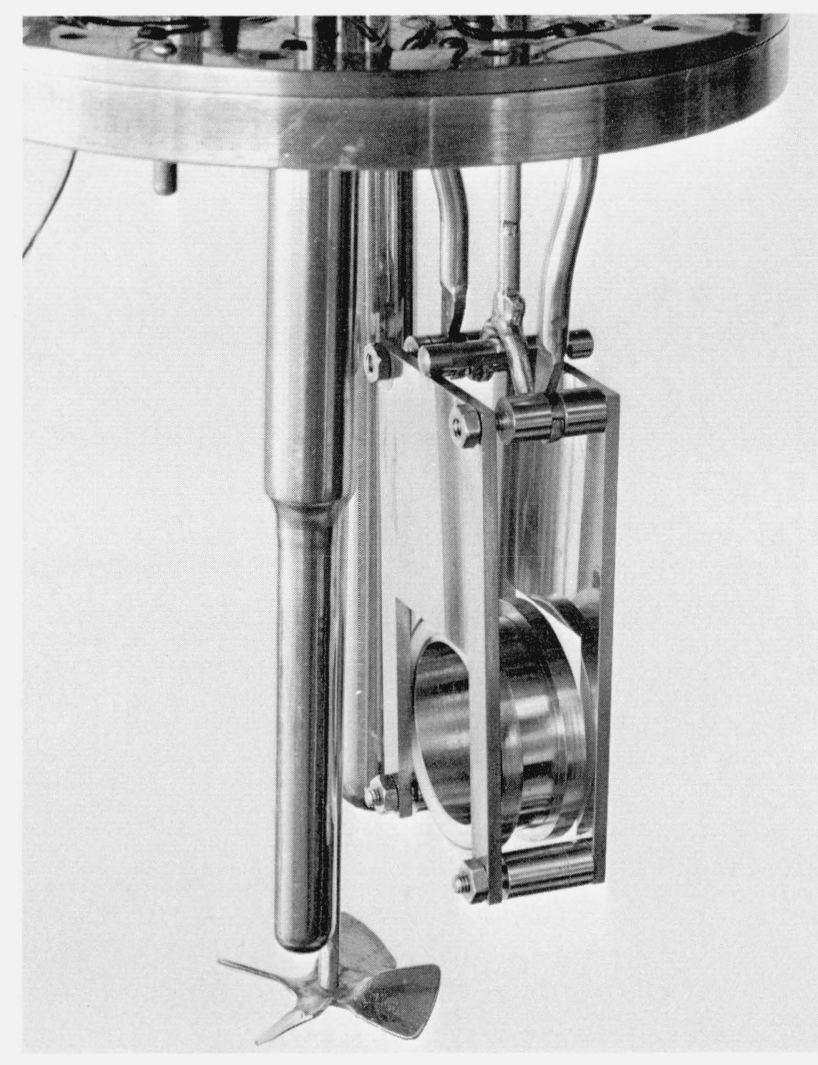

FIGURE 1. Platinum parts inside the vessel of the adiabatic solution calorimeter.

From left, the thermometer well, the stirrer, the heater well (rear), and the sample holder. The sample is contained in the cylinder which initially is at the top and sealed be tween the two flat plates by the PTFE o-rings. The plates are held together by the "trigger" bar (at top) until the initiation of reaction when the trigger bar releases the front plate allowing the cylinder to drop to the position shown here.

In each experiment, the chemical reaction was preceded by an electrical calibration of the initial system and followed by an electrical calibration of the final system. Details of procedures and calculations for electrical calibrations and temperature measurements have been described [15].

\section{Enthalpies of Solution of the Reagent Salts in $\mathrm{H}_{2} \mathrm{O}$}

The enthalpies of solution in $\mathrm{H}_{2} \mathrm{O}$ were measured for each of the salts used as crystalline samples in the experiments reported in sections 4 and 5 . The data are given in table 2.

In the table, the Expt. No. is the serial number of experiments measured in this calorimeter, $\Delta R c$ is the corrected temperature rise during the chemical reaction period, $\overline{E E E}$ is the mean of the electrical energy equivalents for the initial and final systems (the average difference between the values for the initial and final systems was $0.1 \%$ and the maximum difference, $0.35 \%), Q r$ is the product of $\Delta R c$ and $\overline{E E E}$, and $\bar{T}$ reaction is the mean temperature of reaction. The corrected temperature rise, $\Delta R c$, is calculated as the difference between the final and initial temperatures, obtained by solving the linear least-squares-fitted equations of the final and initial rating periods for the temperatures at the time of initiating the reaction. The stirring energy represents the difference between the total and the corrected temperature rise (see [15] for details about the stirring energy). The uncertainty in the stirring energy is about 5 percent or less of the stirring energy.

The heat of the chemical reaction, $Q_{s}$, is obtained by subtracting the precisely-measured "Electrical energy added" during the endothermic chemical reaction from $Q r$. The isothermal enthalpy of reaction, $\Delta H r(T)$, at the temperature of reaction (defined as the mean temperature of reaction) is $-Q s /$ (mass of solute). The temperature of reaction for all of these measurements was near $298.15 \mathrm{~K}$. The concentrations of the final solutions were varied by using differing amounts of solute. Corrections, given in column 12, were made to the enthalpy of reaction using the heat capacity and dilution data from the review by Parker [14] to obtain the enthalpy of solution at $298.15 \mathrm{~K}$ and infinite dilution, $\Delta H^{\circ}(\infty)$, except for $\mathrm{AgNO}_{3}$, where the dilution data obtained in this work (see table 3 and sec. 4) were used. The differences in concentration of the solute had little if any effect on the values obtained for $\Delta H^{\circ}(\infty)$.

In Expt. No. 570, the rate of electrical heating during the chemical reaction was not sufficient to compensate for the heat absorbed by the chemical reaction when the sample holder was opened. Consequently, an abnormal temperature difference between the calorimeter vessel and the adiabatic shield occurred. A correction of $-0.06 \mathrm{~J}$ (see [15] for the method of calculating the correction) was applied to the net heat evolved during the chemical reaction period, $Q r$.

In Expt. No. 582 the calorimeter was sealed by replacing the usual polytetrafluoroethylene o-ring bearing for the stirrer with a heavily lubricated nitrile o-ring and sealing the vent tube with the weighted platinum rod as described in [18]. This was to test the effect on the enthalpy of solution of the unvented calorimeter as compared to the usual vented calorimeter. It was found in our work with Standard Reference Material No. 724a, tris(hydroxymethyl)aminomethane, in $0.1 \mathrm{~N} \mathrm{HCl}$ solution [18] that the enthalpy values obtained with the unvented (closed) calorimeter were about 3 percent more exothermic than those obtained with the calorimeter which was vented or open to the atmosphere. On the other hand no venting effect was found in the reactions of $\mathrm{H}_{2} \mathrm{SO}_{4} \cdot 8 \mathrm{H}_{2} \mathrm{O}$ with 0.02 and $0.08 \mathrm{~N} \mathrm{NaOH}$ solutions [15], nor in the endothermic reaction of TRIS in $\mathrm{NaOH}(\mathrm{aq})$ [18]. In the present work, the enthalpy of solution in Expt. No. 582 using the unvented calorimeter is in satisfactory agreement with those in Expt. Nos. 570 and 571 in which the calorimeter was vented to the atmosphere. This is further evidence that the venting effect is characteristic of the reaction of SRM 724a in HCl(aq), and not a peculiarity of this calorimeter. 
TABLE 2. Data for the calorimetric measurements of $\Delta \mathrm{H}$ soln in $\mathrm{H}_{2} \mathrm{O}$ for the solute reagents used in the precipitation reactions

\begin{tabular}{|c|c|c|c|c|c|c|c|c|c|c|c|c|c|}
\hline $\begin{array}{c}\text { Expt. } \\
\text { No. }\end{array}$ & $\begin{array}{c}\text { Mass } \\
\text { of } \\
\text { solute }\end{array}$ & $\begin{array}{c}\text { Mole ratio } \\
\text { solute } \\
\mathrm{H}_{2} \mathrm{O}:\end{array}$ & $\overline{E E E}$ & $\begin{array}{c}\text { Stirring }{ }^{a} \\
\text { energy }\end{array}$ & $\Delta R c$ & $\bar{T}$ reaction & $Q r$ & $\begin{array}{l}\text { Electrical } \\
\text { energy } \\
\text { added }\end{array}$ & Qs & $\Delta H r(T)$ & Correction & \multicolumn{2}{|c|}{$\Delta H^{\circ}(\infty)(298.15 \mathrm{~K})$} \\
\hline & $\begin{array}{c}g \\
\text { Solute: } \mathrm{K}\end{array}$ & & $J \cdot \Omega^{-1}$ & $\Omega$ & $\Omega$ & $K$ & $J$ & $J$ & $J$ & $J \cdot g^{-1}$ & $\mathrm{~kJ} \cdot \mathrm{mol}^{-1}$ & $k J \cdot \mathrm{mol}^{-1}$ & $\mathrm{kcal} \cdot \mathrm{mol}^{-1}$ \\
\hline $\begin{array}{l}570 \\
571 \\
582\end{array}$ & \begin{tabular}{|}
2.23251 \\
1.32476 \\
2.21843 \\
\\
Solute: KH
\end{tabular} & 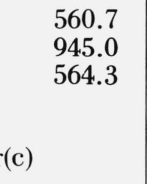 & $\begin{array}{l}17,166.3 \\
17,173.3 \\
17,163.0\end{array}$ & $\begin{array}{r}0.001494 \\
.001066 \\
.001696\end{array}$ & $\begin{array}{r}0.021240 \\
.052533 \\
.041378\end{array}$ & $\begin{array}{l}298.121 \\
297.950 \\
297.899\end{array}$ & $\begin{array}{r}{ }^{b} 364.55 \\
902.16 \\
710.17\end{array}$ & $\begin{array}{r}889.304 \\
1213.292 \\
1233.850\end{array}$ & $\begin{array}{l}-524.75 \\
-311.13 \\
-523.68\end{array}$ & $\begin{array}{l}235.05 \\
234.86 \\
236.06\end{array}$ & $\begin{array}{r}-0.339 \\
-.300 \\
-.339 \\
\text { (Mean) }\end{array}$ & $\begin{array}{l}17.185 \\
17.210 \\
17.260 \\
17.218\end{array}$ & $\begin{array}{l}4.107 \\
4.113 \\
4.125 \\
4.115\end{array}$ \\
\hline $\begin{array}{l}572 \\
573\end{array}$ & $\begin{array}{r}2.38555 \\
4.69414 \\
\\
\text { Solute: AgN }\end{array}$ & $\begin{array}{r}837.7 \\
425.7 \\
\\
\mathrm{O}_{3}(\mathrm{c})\end{array}$ & $\begin{array}{l}17,172.6 \\
17,161.3\end{array}$ & $\begin{array}{r}0.001442 \\
.001462\end{array}$ & $\begin{array}{r}0.047350 \\
.024852\end{array}$ & $\begin{array}{l}298.256 \\
298.084\end{array}$ & $\begin{array}{l}813.12 \\
426.49\end{array}$ & $\begin{array}{l}1214.322 \\
1218.319\end{array}$ & $\begin{array}{l}-401.20 \\
-791.83\end{array}$ & $\begin{array}{l}168.18 \\
168.68\end{array}$ & $\begin{array}{r}-0.255 \\
-.290 \\
(\text { Mean) }\end{array}$ & $\begin{array}{l}19.759 \\
19.784 \\
19.772\end{array}$ & $\begin{array}{l}4.722 \\
4.728 \\
4.725\end{array}$ \\
\hline $\begin{array}{l}574 \\
575\end{array}$ & $\begin{array}{l}2.55356 \\
5.00255\end{array}$ & $\begin{array}{r}1117.0 \\
570.1\end{array}$ & $\begin{array}{r}17,182.3 \\
17,187.7 \\
J \cdot K^{-1}\end{array}$ & $\begin{array}{c}0.001023 \\
.001417 \\
K\end{array}$ & $\begin{array}{c}0.050921 \\
.031904 \\
K\end{array}$ & $\begin{array}{l}298.238 \\
297.932\end{array}$ & $\begin{array}{l}874.94 \\
548.36\end{array}$ & $\begin{array}{l}1216.506 \\
1216.424\end{array}$ & $\begin{array}{l}-341.57 \\
-668.06\end{array}$ & $\begin{array}{l}133.76 \\
133.54\end{array}$ & $\begin{array}{r}-0.003 \\
+.047\end{array}$ & $\begin{array}{r}22.719 \\
22.732 \\
\end{array}$ & $\begin{array}{l}5.430 \\
5.433\end{array}$ \\
\hline $\begin{array}{l}\text { c } 730 \\
\text { c } 737 \\
\text { c } 739\end{array}$ & $\begin{array}{l}1.08990 \\
0.56601 \\
0.28578\end{array}$ & $\begin{array}{l}2616.7 \\
5038.1 \\
9979.1\end{array}$ & $\begin{array}{l}1,732.60 \\
1,731.54 \\
1,733.53\end{array}$ & $\begin{array}{r}0.01108 \\
.01472 \\
.00623\end{array}$ & $\begin{array}{r}0.13472 \\
.17311 \\
.06395\end{array}$ & $\begin{array}{l}298.115 \\
298.373 \\
298.174\end{array}$ & $\begin{array}{l}233.41 \\
299.75 \\
110.85\end{array}$ & $\begin{array}{l}379.622 \\
375.687 \\
149.280\end{array}$ & $\begin{array}{r}-146.21 \\
-75.94 \\
-38.43 \\
(\mathrm{Gra}\end{array}$ & $\begin{array}{r}134.15 \\
134.17 \\
134.46 \\
\text { hical limit }\end{array}$ & $\begin{array}{c}-0.085 \\
-.071 \\
-.104 \\
\text { see text) }\end{array}$ & $\begin{array}{l}22.703 \\
22.721 \\
22.737 \\
22.727\end{array}$ & $\begin{array}{l}5.426 \\
5.430 \\
5.434 \\
5.432\end{array}$ \\
\hline
\end{tabular}

${ }^{a}$ The stirring rate in all experiments was $550 \mathrm{rpm}$ except Expt. Nos. 730 and 737 $(450 \mathrm{rpm})$ and No. $739(250 \mathrm{rpm})$.

${ }^{b}$ A correction of $-0.06 \mathrm{~J}$ was applied because of the lar

$c$ The calorimeter temperature was measured with a quartz-oscillator thermometer. 
TABLE 3. Apparent relative molal heat content of $\mathrm{AgNO}_{3} \cdot \mathrm{n}_{2} \mathrm{O}(\mathrm{aq})$ at $298.15 \mathrm{~K}$

\begin{tabular}{c|r|r|r|r}
\hline \hline \multirow{2}{*}{$m$} & \multirow{2}{*}{$n$} & \multicolumn{3}{|c}{$\phi_{L}$ or $-\Delta H$ diln } \\
\cline { 3 - 5 } & & \multicolumn{2}{|c}{ This work } & Parker [14] \\
\cline { 3 - 5 } molality & & $J \cdot \mathrm{mol}^{-1}$ & $\mathrm{cal} \cdot \mathrm{mol}^{-1}$ & ${\mathrm{cal} \cdot \mathrm{mol}^{-1}}$ \\
$5.551 \times 10^{-4}$ & 100,000 & 46 & 11 & 9 \\
$1.110 \times 10^{-3}$ & 50,000 & 64 & 15 & 12 \\
$2.775 \times 10^{-3}$ & 20,000 & 89 & 21 & 17 \\
$5.551 \times 10^{-3}$ & 10,000 & 105 & 25 & 19 \\
$1.110 \times 10^{-2}$ & 5,000 & 102 & 24 & 21 \\
$1.388 \times 10^{-2}$ & 4,000 & 97 & 23 & 16 \\
$1.850 \times 10^{-2}$ & 3,000 & 86 & 21 & 12 \\
$2.775 \times 10^{-2}$ & 2,000 & 64 & 15 & 2 \\
$3.700 \times 10^{-2}$ & 1,500 & 42 & 10 & -6 \\
$5.551 \times 10^{-2}$ & 1,000 & -3 & -1 & -20 \\
$6.938 \times 10^{-2}$ & 800 & -35 & -8 & -32 \\
$9.251 \times 10^{-2}$ & 600 & -76 & -18 & -27 \\
$1.110 \times 10^{-1}$ & 500 & -112 & -27 & 20 \\
\hline
\end{tabular}

Parker's "best" values [14] for $\Delta H^{\circ}(\infty)$ (in $\mathrm{kJ} \cdot \mathrm{mol}^{-1}$ ) are $17.22 \pm 0.04$ for $\mathrm{KCl}(\mathrm{c}), 19.87 \pm 0.08$ for $\mathrm{KBr}(\mathrm{c})$, and $22.59 \pm 0.21$ for $\mathrm{AgNO}_{3}$ (c). Our mean value given in table 2 for $\mathrm{KCl}$ is in excellent agreement with Parker's value. Our mean value for $\mathrm{KBr}$ differs by about 0.5 percent from Parker's selected value but is within 0.02 percent of the recent results of Tsvetkov and Rabinovich [19]. The uncertainty in Parker's "best" value for $\mathrm{AgNO}_{3}$ is relatively large, and the mean of our measured values falls near the upper limit of the uncertainty.

\section{Enthalpies of Solution and Dilution of $\mathrm{AgNO}_{3}$}

The measurements on the enthalpy of solution of $\mathrm{AgNO}_{3}(\mathrm{c})$ given in table 2 were extrapolated to infinite dilution using the relation [20]

$$
\Delta H-\phi_{L}=\Delta H^{\circ}(\infty)=\Delta H-2879 m^{1 / 2} \times \rho+f(m)
$$

where

$$
\begin{aligned}
& \rho=\left(1+m^{1 / 2}\right)^{-1}-\left(1 / m^{3 / 2}\right) \\
& {\left[1+m^{1 / 2}-\left(1 /\left(1+m^{1 / 2}\right)\right)-2 \ln \left(1+m^{1 / 2}\right)\right] .}
\end{aligned}
$$

A plot of $\Delta H-2879 m^{1 / 2} \rho\left(=\Delta H^{\prime}\right)$ against the molality, $m$, yielded a curve linear below $m=0.05$ with the intercept, $\Delta H^{\circ}(\infty)=22.727 \pm 0.029 \mathrm{~kJ} \cdot \mathrm{mol}^{-1}(5.432 \pm$ $\left.0.007 \mathrm{kcal} \cdot \mathrm{mol}^{-1}\right)$. From this value of $\Delta H^{\circ}(\infty)$, values of $\phi_{L}$ were calculated for each measured concentration and a smooth curve plotted versus $m^{1 / 2}$. Values of $\phi_{L}$ were interpolated from the curve and are given in table 3 for various values of $m$. We estimate the uncertainty in $\phi_{L}$ to be about $\pm 10 \mathrm{~J} \cdot \mathrm{mol}^{-1}( \pm 2$ $\left.\mathrm{cal} \cdot \mathrm{mol}^{-1}\right)$. Corresponding values estimated by Parker [14] are also shown in the table. Parker's values were obtained from very limited data and the present work indicates that her estimates were only slightly in error.

A summary of earlier calorimetric measurements

\begin{tabular}{|c|c|c|c|}
\hline Investigator & \multicolumn{2}{|c|}{$\Delta H^{\circ}(\infty)$} & Reference \\
\hline Thomsen (1883).. & $\begin{array}{c}\mathrm{kJ} \cdot \mathrm{mol}^{-1} \\
22.51 \pm 0.21\end{array}$ & $\begin{array}{l}\mathrm{kcal} \cdot \mathrm{mol}^{-1} \\
5.38 \pm 0.05\end{array}$ & {$[6]$} \\
\hline Roth (1944)........... & $22.573 \pm 0.21$ & $5.395 \pm 0.050$ & [9] \\
\hline $\begin{array}{l}\text { Lange and Martin } \\
(1937) \ldots \ldots \ldots \ldots \ldots \ldots\end{array}$ & 22.907 & 5.475 & {$[21]$} \\
\hline $\begin{array}{l}\text { Smith, Brown, and } \\
\text { Pitzer (1937) ......... }\end{array}$ & $22.468 \pm 0.21$ & $5.370 \pm 0.050$ & {$[22]$} \\
\hline $\begin{array}{l}\text { Graham and Hepler } \\
(1958) \ldots \ldots \ldots \ldots \ldots \ldots \ldots \ldots \ldots \ldots\end{array}$ & $22.740 \pm 0.17$ & $5.435 \pm 0.040$ & {$[23]$} \\
\hline $\begin{array}{l}\text { Shidlovskii and Voskre- } \\
\text { senskii }(1963) \ldots \ldots \ldots \ldots .\end{array}$ & 22.38 & 5.35 & {$[24]$} \\
\hline 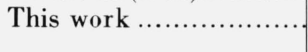 & $22.727 \pm 0.084$ & $5.432 \pm 0.020$ & \\
\hline Selected Value... & $22.730 \pm 0.084$ & $5.433 \pm 0.020$ & \\
\hline
\end{tabular}
of the enthalpy of solution of $\mathrm{AgNO}_{3}$ (c) (corrected to
TABLE 4. Enthalpy of solution of $\mathrm{AgNO}_{3}$ in $\mathrm{H}_{2} \mathrm{O}$ at $298.15 \mathrm{~K}$

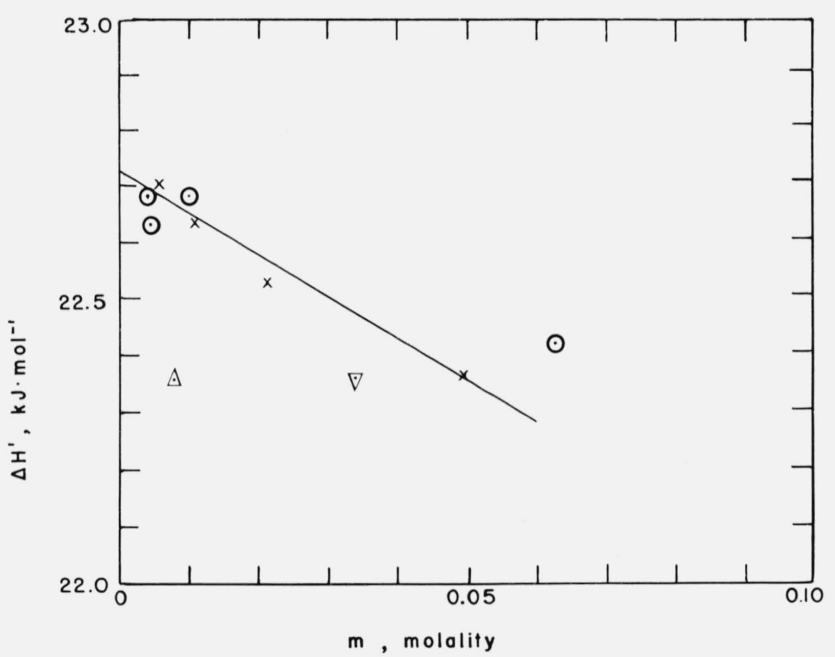

FIGURE 2. Extrapolation of heat of solution measurements on $\mathrm{AgNO}_{3}$ in the dilute range below 0.05 molal) to infinite dilution at $298.15 \mathrm{~K}$.

$\odot$ Graham and Hepler [23]; $\triangle$ Smith, Brown, and Pitzer [22]; $\nabla$ Roth [9]; X This work. (See sec. 4.)

infinite dilution) is given in table 4. We have combined our dilute solution measurements with those of Graham and Hepler [23] and extrapolated the combined set of data as described above to obtain a selected best value of $\Delta H^{\circ}(\infty)=22.730 \pm 0.042 \mathrm{~kJ} \cdot \mathrm{mol}^{-1}$ or $5.433 \pm 0.010 \mathrm{kcal} \cdot \mathrm{mol}^{-1}$ (see fig. 2 ).

\section{Silver Halide Precipitation Experiments}

The enthalpies of reaction were measured for five reactions in which the silver halide precipitates were formed: $\mathrm{KCl}(\mathrm{c})$ in $0.15 \mathrm{~N} \mathrm{AgNO}_{3}(\mathrm{aq})$, reaction I;

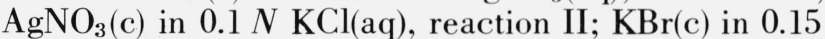
$N \mathrm{AgNO}_{3}(\mathrm{aq})$, reaction III; $\mathrm{AgNO}_{3}(\mathrm{c})$ in $0.1 \mathrm{~N} \mathrm{KBr}(\mathrm{aq})$, reaction IV; and $\mathrm{AgNO}_{3}(\mathrm{c})$ in $0.1 \mathrm{~N} \mathrm{KI}(\mathrm{aq})$, reaction $\mathrm{V}$. The reaction which would complete the set, $\mathrm{KI}(\mathrm{c})$, in $\mathrm{AgNO}_{3}(\mathrm{aq})$, was not measured because of time limita- 
tions. The results of the five reactions measured here were sufficient to produce the desired information. The fluoride reactions were not included because of large uncertainties in the related data.

The data for the 21 silver halide precipitation experiments are given in tables 5 and 6 . Explanations of Expt. No., $\triangle R c, \overline{E E E}, Q r, \bar{T}$ reaction, and Stirring energy are given in section 3 and [15]. In these tables and the discussions, solute refers to the crystalline samples of $\mathrm{KCl}, \mathrm{KBr}$, and $\mathrm{AgNO}_{3}$, and solvent salt refers to the $\mathrm{KCl}, \mathrm{KBr}$, or $\mathrm{AgNO}_{3}$ dissolved in the initial aqueous calorimetric solutions. In each group of reactions, there is one experiment in which the mass of solute was approximately half that used in the other experiments. The variations in the concentration of the solute had a negligible effect on the enthalpy of reaction in this range.

In preliminary experiments (not given in the tables) we encountered some of the difficulties to be expected in this type of reaction. Upon initiating the reaction, there was the expected rapid increase in the calorimeter temperature; after $15 \mathrm{~min}$, the slope of the time- temperature curve was about ten times that preceding the reaction; after three hours, the slope was about three times that of the initial rating period for the reaction, indicating that heat was still being evolved but at a slowly decreasing rate. Upon opening the calorimeter vessel, we found (in addition to the expected flocculent precipitates, white $\mathrm{AgCl}$ and yellow $\mathrm{AgBr}$ ) at the bottom of the vessel a solid mass of material (which assumed the shape of the vessel) covered by a thin sheet of material which had a paper-like consistency when dried. Apparently the samples, of higher density than the solutions, had fallen to the bottom of the vessel. The precipitates formed a protective layer over the unreacted sample and inhibited access of the solution to the crystalline sample. In Expt. No. 568 (reaction I, tables 5 and 6 ) the stirring rate was increased from $350 \mathrm{rpm}$ to $550 \mathrm{rpm}$ and after $50 \mathrm{~min}$ the slope of the time-temperature curve was approximately equal to that of the rating period preceding the reaction. All of the product was the flocculent, white AgCl with no evidence of the incomplete reaction. The stirring rate of $550 \mathrm{rpm}$ was used in all experiments given in table 6.

TABLE 5. Data for the silver halide precipitation experiments

\begin{tabular}{|c|c|c|c|c|c|c|c|c|}
\hline \multirow{2}{*}{$\begin{array}{l}\text { Expt. } \\
\text { No. }\end{array}$} & \multirow{2}{*}{$\begin{array}{l}\text { Reaction } \\
\text { period }\end{array}$} & \multicolumn{3}{|c|}{ Solvent composition } & \multirow{2}{*}{ Solute } & \multicolumn{3}{|c|}{ Mole ratios } \\
\hline & & Conc. & Salt & $\mathrm{H}_{2} \mathrm{O}$ & & $\mathrm{H}_{2} \mathrm{O}$ : solute & $\begin{array}{l}\text { Solvent } \\
\text { salt solute }\end{array}$ & $\mathrm{H}_{2} \mathrm{O}: \begin{array}{l}\text { solvent } \\
\text { salt }\end{array}$ \\
\hline & $\min$ & $w t \%$ & mol & mol & mol & & & \\
\hline \multicolumn{9}{|c|}{ Reaction I: $\mathrm{KCl}(\mathrm{c})$ in $0.15 \mathrm{~N} \mathrm{AgNO}_{3}(\mathrm{aq})$} \\
\hline $\begin{array}{l}568 \\
581 \\
605 \\
606 \\
607 \\
608\end{array}$ & $\begin{array}{c}50 \\
50 \\
25 \\
170 \\
>30,<95 \\
25\end{array}$ & $\begin{array}{l}2.55 \\
2.55 \\
2.49 \\
2.49 \\
2.49 \\
2.49\end{array}$ & $\begin{array}{r}0.04695 \\
.04697 \\
.04576 \\
.04575 \\
.04576 \\
.04575\end{array}$ & $\begin{array}{l}16.906 \\
16.906 \\
16.916 \\
16.916 \\
16.917 \\
16.916\end{array}$ & $\begin{array}{r}0.029933 \\
.029840 \\
.029109 \\
.029208 \\
.027368 \\
.014717\end{array}$ & $\begin{array}{r}565 \\
567 \\
581 \\
579 \\
618 \\
1542\end{array}$ & $\begin{array}{l}1.57 \\
1.57 \\
1.57 \\
1.57 \\
1.67 \\
3.11\end{array}$ & $\begin{array}{l}360 \\
360 \\
370 \\
370 \\
370 \\
370\end{array}$ \\
\hline \multicolumn{9}{|c|}{ Reaction II: $\mathrm{AgNO}_{3}(\mathrm{c})$ in $0.1 N \mathrm{KCl}(\mathrm{aq})$} \\
\hline $\begin{array}{l}576 \\
577 \\
610\end{array}$ & $\begin{array}{l}15 \\
20 \\
20\end{array}$ & $\begin{array}{l}0.75 \\
0.75 \\
0.75\end{array}$ & $\begin{array}{r}0.03031 \\
.03031 \\
.03031\end{array}$ & $\begin{array}{l}16.666 \\
16.667 \\
16.668\end{array}$ & $\begin{array}{r}0.015088 \\
.029455 \\
.023224\end{array}$ & $\begin{array}{r}1104 \\
566 \\
718\end{array}$ & $\begin{array}{l}2.01 \\
1.03 \\
1.30\end{array}$ & $\begin{array}{l}550 \\
550 \\
550\end{array}$ \\
\hline \multicolumn{9}{|c|}{ Reaction III: $\mathrm{KBr}(\mathrm{c})$ in $0.15 \mathrm{~N} \mathrm{AgNO}_{3}(\mathrm{aq})$} \\
\hline $\begin{array}{l}569 \\
601 \\
604 \\
609\end{array}$ & $\begin{array}{c}15 \\
15 \\
165 \\
>45,<75\end{array}$ & $\begin{array}{l}2.55 \\
2.48 \\
2.49 \\
2.48\end{array}$ & $\begin{array}{r}0.04696 \\
.04569 \\
.04574 \\
.04569\end{array}$ & $\begin{array}{l}16.903 \\
16.918 \\
16.916 \\
16.917\end{array}$ & $\begin{array}{r}0.039752 \\
.020192 \\
.039782 \\
.033619\end{array}$ & $\begin{array}{l}425 \\
838 \\
425 \\
503\end{array}$ & $\begin{array}{l}1.18 \\
2.26 \\
1.15 \\
1.36\end{array}$ & $\begin{array}{l}360 \\
370 \\
370 \\
370\end{array}$ \\
\hline \multicolumn{9}{|c|}{ Reaction IV: $\mathrm{AgNO}_{3}(\mathrm{c})$ in $0.1 N \mathrm{KBr}(\mathrm{aq})$} \\
\hline $\begin{array}{l}578 \\
579 \\
580\end{array}$ & $\begin{array}{l}15 \\
20 \\
70\end{array}$ & $\begin{array}{l}1.19 \\
1.19 \\
1.19\end{array}$ & $\begin{array}{r}0.03025 \\
.03024 \\
.03025\end{array}$ & $\begin{array}{l}16.591 \\
16.590 \\
16.591\end{array}$ & $\begin{array}{r}0.014998 \\
.029396 \\
.029491\end{array}$ & $\begin{array}{r}1106 \\
564 \\
563\end{array}$ & $\begin{array}{l}2.02 \\
1.03 \\
1.03\end{array}$ & $\begin{array}{l}548 \\
549 \\
548\end{array}$ \\
\hline \multicolumn{9}{|c|}{ Reaction $\mathrm{V}: \mathrm{AgNO}_{3}(\mathrm{c})$ in $0.1 N \mathrm{KI}(\mathrm{aq})$} \\
\hline $\begin{array}{l}596 \\
597 \\
598 \\
599 \\
600\end{array}$ & $\begin{array}{l}20 \\
20 \\
20 \\
20 \\
20\end{array}$ & $\begin{array}{l}1.67 \\
1.67 \\
1.67 \\
1.67 \\
1.67\end{array}$ & $\begin{array}{r}0.03040 \\
.03040 \\
.03040 \\
.03040 \\
.03040\end{array}$ & $\begin{array}{l}16.513 \\
16.513 \\
16.513 \\
16.512 \\
16.512\end{array}$ & $\begin{array}{r}0.023597 \\
.015137 \\
.023668 \\
.023666 \\
.023471\end{array}$ & $\begin{array}{r}700 \\
1091 \\
698 \\
698 \\
704\end{array}$ & $\begin{array}{l}1.29 \\
2.01 \\
1.28 \\
1.28 \\
1.30\end{array}$ & $\begin{array}{l}543 \\
543 \\
543 \\
543 \\
543\end{array}$ \\
\hline
\end{tabular}


TABLE 6. Calorimetric data for the silver halide precipitation experiments

\begin{tabular}{|c|c|c|c|c|c|c|c|c|c|c|c|}
\hline \multirow{2}{*}{$\begin{array}{c}\text { Expt. } \\
\text { No. }\end{array}$} & \multirow{2}{*}{$\begin{array}{c}\begin{array}{c}\text { Stirring } \\
\text { energy }\end{array} \\
\Omega\end{array}$} & \multirow{2}{*}{$\begin{array}{c}\Delta R c \\
\Omega\end{array}$} & \multirow{2}{*}{$\begin{array}{c}\overline{E E E} \\
J \cdot \Omega^{-1}\end{array}$} & \multirow{2}{*}{$\begin{array}{l}Q r \\
J\end{array}$} & \multirow{2}{*}{$\begin{array}{c}\begin{array}{c}\text { Mass of } \\
\text { solute }\end{array} \\
g\end{array}$} & \multirow{2}{*}{\begin{tabular}{|c|}
$\bar{T}$ reaction \\
$K$
\end{tabular}} & \multicolumn{2}{|c|}{$-\Delta H r(T)$} & \multirow{2}{*}{$\begin{array}{c}\Delta C p \\
J \cdot \mathrm{mol}^{-1} \cdot \mathrm{K}^{-1}\end{array}$} & \multicolumn{2}{|c|}{$-\Delta H r(298.15 \mathrm{~K})$} \\
\hline & & & & & & & $J \cdot g^{-1}$ & $\mathrm{~kJ} \cdot \mathrm{mol}^{-1}$ & & $\mathrm{~kJ} \cdot \mathrm{mol}^{-1}$ & $\mathrm{kcal} \cdot \mathrm{mol}^{-1}$ \\
\hline \multicolumn{12}{|c|}{ Reaction I: $\mathrm{KCl}(\mathrm{c})$ in $\mathrm{AgNO}_{3}(\mathrm{aq})$} \\
\hline 568 & 0.002368 & 0.084251 & $17,265.7$ & 1454.65 & 2.23165 & 298.056 & 651.83 & 48.597 & -19.5 & 48.599 & 11.615 \\
\hline 581 & .002628 & .083919 & $17,336.4$ & 1454.85 & 2.22464 & 308.518 & 653.97 & 48.757 & & 48.555 & 11.605 \\
\hline 605 & .001748 & .081933 & $17,337.7$ & 1420.54 & 2.17024 & 308.552 & 654.55 & 48.800 & & 48.597 & 11.615 \\
\hline 606 & .007200 & .082146 & $17,267.8$ & 1418.49 & 2.17762 & 298.147 & 651.40 & 48.565 & & 48.565 & 11.607 \\
\hline 607 & .004361 & .077058 & $17,339.4$ & 1336.14 & 2.04045 & 308.489 & 654.83 & 48.821 & & 48.619 & 11.620 \\
\hline 608 & .001622 & .041431 & $17,264.3$ & 715.28 & 1.09727 & 298.438 & 651.87 & 48.600 & & 48.594 & 11.614 \\
\hline & & & & & & & & & & $\begin{array}{c}\text { Mean }=48.588 \\
\mathrm{sdm}= \pm 0.010\end{array}$ & $\begin{array}{r}11.613 \\
\pm 0.002\end{array}$ \\
\hline \multicolumn{12}{|c|}{ Reaction II: $\mathrm{AgNO}_{3}(\mathrm{c})$ in $\mathrm{KCl}(\mathrm{aq})$} \\
\hline 576 & 0.001448 & 0.038460 & $17,068.8$ & 656.48 & 2.56312 & 298.389 & 256.13 & 43.510 & +21.8 & 43.515 & 10.400 \\
\hline 577 & .001739 & .075132 & $17,085.2$ & 1283.64 & 5.00369 & 297.448 & 256.54 & 43.579 & & 43.564 & 10.412 \\
\hline 610 & .001756 & .058692 & $17,140.8$ & 1006.02 & 3.94511 & 308.424 & 255.00 & 43.318 & & 43.542 & 10.407 \\
\hline & & & & & & & & & & $\begin{array}{c}\text { Mean }=43.540 \\
\text { sdm }= \pm 0.014\end{array}$ & $\begin{array}{r}10.406 \\
\pm 0.003\end{array}$ \\
\hline \multicolumn{12}{|c|}{ Reaction III: $\mathrm{KBr}(\mathrm{c})$ in $\mathrm{AgNO}_{3}(\mathrm{aq})$} \\
\hline 569 & 0.001553 & 0.149914 & $17,276.1$ & 2589.92 & 4.73088 & 298.171 & 547.45 & 65.150 & -13.0 & 65.150 & 15.571 \\
\hline 601 & .001593 & .076239 & 17.268 .5 & 1316.54 & 2.40302 & 298.218 & 547.87 & 65.200 & & 65.199 & 15.583 \\
\hline 604 & .005978 & .150107 & $17,267.6$ & 2591.98 & 4.73452 & 297.849 & 547.46 & 65.151 & & 65.155 & 15.572 \\
\hline 609 & .003698 & .126733 & $17,324.2$ & 2195.55 & 4.00098 & 308.785 & 548.75 & 65.304 & & 65.166 & 15.575 \\
\hline & & & & & & & & & & Mean $=65.168$ & $\begin{array}{r}15.575 \\
+0.003\end{array}$ \\
\hline \multirow{2}{*}{\multicolumn{12}{|c|}{ Reaction IV: $\mathrm{AgNO}_{3}(\mathrm{c})$ in $\mathrm{KBr}(\mathrm{aq})$}} \\
\hline & & & & & & & & & & & \\
\hline 578 & 0.001682 & 0.055171 & $17,011.4$ & 938.54 & 2.54781 & 297.993 & 368.37 & 62.576 & +63. & 62.566 & 14.954 \\
\hline 579 & .003097 & .108010 & $17,026.8$ & 1839.07 & 4.99368 & 297.772 & 368.28 & 62.561 & & 62.537 & 14.947 \\
\hline 580 & .005479 & .106780 & $17,094.4$ & 1825.34 & 5.00979 & 308.638 & 364.36 & 61.895 & & 62.556 & 14.951 \\
\hline & & & & & & & & & & Mean $=62.553$ & $\begin{array}{r}14.951 \\
+0.002\end{array}$ \\
\hline \multirow{2}{*}{\multicolumn{12}{|c|}{ Reaction $\mathrm{V}: \mathrm{AgNO}_{3}(\mathrm{c})$ in $\mathrm{KI}(\mathrm{aq})$}} \\
\hline & & & & & & & & & & & \\
\hline 596 & 0.002112 & 0.122965 & $17,031.3$ & 2094.26 & 4.00853 & 308.673 & 522.45 & 88.750 & +9.6 & 88.851 & 21.236 \\
\hline 597 & .001929 & .079234 & $16,957.6$ & 1343.62 & 2.57140 & 298.640 & 522.52 & 88.762 & & 88.767 & 21.216 \\
\hline 598 & .001894 & .123197 & $17,028.9$ & 2097.91 & 4.02068 & 308.772 & 521.78 & 88.636 & & 88.738 & 21.209 \\
\hline 599 & .001895 & .123855 & $16,965.1$ & 2101.22 & 4.02032 & 297.877 & 522.65 & 88.784 & & 88.781 & 21.219 \\
\hline 600 & 001638 & .122122 & $17,033.4$ & 2080.16 & 3.98710 & 308.740 & 521.72 & 88.626 & & 88.728 & 21.206 \\
\hline & & & & & & & & & & Mean $=88.773$ & 21.217 \\
\hline & & & & & & & & & & $\mathrm{sdm}= \pm 0.022$ & \pm 0.005 \\
\hline
\end{tabular}

It may be seen in table 5 that there were occasional experiments (Nos. 580, 604, 606, and 609) where the reaction periods were longer than others in the group. We assume that this was caused by the way in which the sample holder (see fig. 1) opened. Initially the cylinder containing the sample is at the top, between the two flat plates. When the trigger is released to start the reaction, the cylinder falls to the lower crossbars. As the cylinder falls, if it tilts toward the stirrer, most of the sample will be quickly dispersed in the solution; however, if the cylinder tilts away from the stirrer, much of the sample falls to the bottom and is covered by the precipitate formed. This limits access of the solution to the sample. In all of the experiments listed in tables 5 and 6 , the reactions were complete, as evidenced by the essentially equal slopes in the initial and final rating periods and by the absence of products of incomplete reaction such as were found in the first experiments described earlier in this section.

In table 6 , the isothermal enthalpy of reaction at the temperature of reaction is $\Delta H r(T)=-Q r /$ (mass of solute). In each group of reactions, one or more enthalpy measurements were made at $309 \mathrm{~K}$ in order to obtain a value of $\Delta C p$ for the reaction. The enthalpy values at $298.15 \mathrm{~K}$ were calculated using the values of $\Delta C p$ given in the table for each reaction. The mean $\Delta \operatorname{Hr}(298.15 \mathrm{~K})$ and the standard deviations of the mean are given for each group of experiments.

The average reactions for the five groups of experiments are represented by the following equations 
(with uncertainties as the experimental imprecision at the 95 percent confidence level):

$$
\begin{aligned}
& \mathrm{KCl}(\mathrm{c})+1.84\left(\mathrm{AgNO}_{3} \cdot 367 \mathrm{H}_{2} \mathrm{O}\right) \rightarrow \\
& \mathrm{AgCl}(\mathrm{c})+\left(\mathrm{KNO}_{3} \cdot 0.84 \mathrm{AgNO}_{3} \cdot 675.28 \mathrm{H}_{2} \mathrm{O}\right)_{\mathrm{soln}} \\
& \begin{aligned}
\Delta \operatorname{Hr}(298.15 \mathrm{~K}) & =-48.588 \pm 0.025 \mathrm{~kJ} \cdot \mathrm{mol}^{-1} \\
& =-11.613 \pm 0.006 \mathrm{kcal} \cdot \mathrm{mol}^{-1}
\end{aligned}
\end{aligned}
$$

$$
\begin{aligned}
& \mathrm{AgNO}_{3}(\mathrm{c})+1.45(\mathrm{KCl} \cdot 550 \mathrm{H} \mathrm{O}) \rightarrow \\
& \mathrm{AgCl}(\mathrm{c})+\left(\mathrm{KNO}_{3} \cdot 0.45 \mathrm{KCl} \cdot 797.5 \mathrm{H}_{2} \mathrm{O}\right)_{\text {soln }} \\
& \begin{aligned}
\Delta \mathrm{Hr}(298.15 \mathrm{~K}) & =-43.540 \pm 0.060 \mathrm{~kJ} \cdot \mathrm{mol}^{-1} \\
& =-10.406 \pm 0.014 \mathrm{kcal} \cdot \mathrm{mol}^{-1}
\end{aligned}
\end{aligned}
$$

$$
\begin{aligned}
& \mathrm{KBr}(\mathrm{c})+1.49\left(\mathrm{AgNO}_{3} \cdot 368 \mathrm{H}_{2} \mathrm{O}\right) \rightarrow \\
& \operatorname{AgBr}(\mathrm{c})+\left(\mathrm{KNO}_{3} \cdot 0.49 \mathrm{AgNO}_{3} \cdot 548.32 \mathrm{H}_{2} \mathrm{O}\right)_{\mathrm{soln}} \\
& \begin{aligned}
\Delta H r(298.15 \mathrm{~K}) & =-65.168 \pm 0.035 \mathrm{~kJ} \cdot \mathrm{mol}^{-1} \\
& =-15.575 \pm 0.008 \mathrm{kcal} \cdot \mathrm{mol}^{-1}
\end{aligned}
\end{aligned}
$$

$\mathrm{AgNO}_{3}(\mathrm{c})+1.36\left(\mathrm{KBr} \cdot 548 \mathrm{H}_{2} \mathrm{O}\right) \rightarrow$

$\mathrm{AgBr}(\mathrm{c})+\left(\mathrm{KNO}_{3} \cdot 0.36 \mathrm{KBr} \cdot 745.28 \mathrm{H}_{2} \mathrm{O}\right)_{\text {soln }}$

$\Delta H r(298.15 \mathrm{~K})=-62.553 \pm 0.034 \mathrm{~kJ} \cdot \mathrm{mol}^{-1}$

$$
=-14.951 \pm 0.008 \mathrm{kcal} \cdot \mathrm{mol}^{-1}
$$

$$
\begin{aligned}
& \mathrm{AgNO}_{3}(\mathrm{c})+1.43\left(\mathrm{KI} \cdot 543 \mathrm{H}_{2} \mathrm{O}\right) \rightarrow \\
& \mathrm{AgI}(\mathrm{c})+\left(\mathrm{KNO}_{3} \cdot 0.43 \mathrm{KI} \cdot 776.49 \mathrm{H}_{2} \mathrm{O}\right) \\
& \Delta \operatorname{Hr}(298.15 \mathrm{~K})=-88.773 \pm 0.061 \mathrm{~kJ} \cdot \mathrm{mol}^{-1} \\
& =-21.217 \pm 0.014 \mathrm{kcal} \cdot \mathrm{mol}^{-1}
\end{aligned}
$$

\section{Correction for enthalpy of mixing.}

The quantity, $\Delta \operatorname{Hr}(298.15 \mathrm{~K})$, given in table 6 represents the enthalpy change for the generalized reaction:

$\mathrm{KX}(\mathrm{c})+b\left[\mathrm{AgNO}_{3}+n \mathrm{H}_{2} \mathrm{O}\right] \rightarrow$

$$
\mathrm{AgX}(\mathrm{c})+\left[\mathrm{KNO}_{3}+(b-1) \mathrm{AgNO}_{3}+n \cdot b \mathrm{H}_{2} \mathrm{O}\right]
$$

or

$$
\mathrm{AgNO}_{3}(\mathrm{c})+b\left[\mathrm{KX}+n \mathrm{H}_{2} \mathrm{O}\right] \rightarrow
$$

$$
\mathrm{AgX}(\mathrm{c})+\left[\mathrm{KNO}_{3}+(b-1) \mathrm{KX}+n \cdot b \mathrm{H}_{2} \mathrm{O}\right] .
$$

For the systems in which $\mathrm{Ag}^{+}$ion is in excess the enthalpy of mixing reaction,

$$
\begin{array}{r}
{\left[\mathrm{KNO}_{3} \cdot n \mathrm{H}_{2} \mathrm{O}(\mathrm{aq})\right]+(b-1)\left[\mathrm{AgNO}_{3} \cdot n \mathrm{H}_{2} \mathrm{O}\right](\mathrm{aq}) \rightarrow} \\
{\left[\mathrm{KNO}_{3}+(b-1) \mathrm{AgNO}_{3}+n \cdot b \mathrm{H}_{2} \mathrm{O}\right](\mathrm{aq})}
\end{array}
$$

was calculated from the measurement of Karapet'yants, Vlasenko, and Solov'eva [25]. Their data were fitted to a function of the form

$$
\Delta H \operatorname{mix}=\mathrm{X}(1-\mathrm{X}) m^{2} \mathrm{RTh}_{0}
$$

in which $\mathrm{X}$ is the mole fraction of $\mathrm{AgNO}_{3}$ in the solute mixture, $m$ is the molality of the solution, and $\Delta H$ mix is the enthalpy of mixing per kilogram of solvent [26]. For $m=0.15$ we obtained the equation

$$
\Delta H_{\operatorname{mix}}=-3.95 \mathrm{X}(1-\mathrm{X}), \mathrm{J} \cdot\left(k g \mathrm{H}_{2} \mathrm{O}\right)^{-1} .
$$

The enthalpy of mixing per mole of solute was then computed from the equation

$$
\Delta H \operatorname{mix}=-\frac{b-1}{b} \times \frac{n}{55.51} \times 3.95, \mathrm{~J} \cdot \mathrm{mol}^{-1} .
$$

For the $\mathrm{KCl}(\mathrm{c})-\mathrm{AgNO}_{3}(\mathrm{aq})$ reactions, the correction to $\Delta H r(-\Delta H$ mix $)$ is $9 \mathrm{~J} \cdot \mathrm{mol}^{-1}$ except for Expt. No. 608 in which the correction is $18 \mathrm{~J} \cdot \mathrm{mol}^{-1}$; the average correction is $10 \mathrm{~J} \cdot \mathrm{mol}^{-1}\left(2.4 \mathrm{cal} \cdot \mathrm{mol}^{-1}\right)$. For the $\mathrm{KBr}(\mathrm{c})-\mathrm{AgNO}_{3}(\mathrm{aq})$ the corrections range from 3 to $15 \mathrm{~J} \cdot \mathrm{mol}^{-1}$, the average correction being $8 \mathrm{~J} \cdot \mathrm{mol}^{-1}$ $\left(1.9 \mathrm{cal} \cdot \mathrm{mol}^{-1}\right)$.

The enthalpy of mixing reaction

$$
\begin{array}{r}
{\left[\mathrm{KNO}_{3} \cdot n \mathrm{H}_{2} \mathrm{O}\right](\mathrm{aq})+(b-\mathrm{l})\left[\mathrm{KCl} \cdot n \mathrm{H}_{2} \mathrm{O}\right](\mathrm{aq}) \rightarrow} \\
{\left[\mathrm{KNO}_{3}+(b-1) \mathrm{KCl}+n \cdot b \mathrm{H}_{2} \mathrm{O}\right](\mathrm{aq})}
\end{array}
$$

was calculated from the data given in $\mathrm{Wu}$, Smith, and Young [26] and Wood and Smith [27] for the KCl $-\mathrm{KNO}_{3}$ system to be less than $1 \mathrm{~J} \cdot \mathrm{mol}^{-1}$ and was omitted. The correction was also assumed to be negligible for the $\mathrm{KBr}-\mathrm{KNO}_{3}$ and $\mathrm{KI}-\mathrm{KNO}_{3}$ systems.

\section{Enthalpies of Precipitation of the Silver Halides}

The measured enthalpies for the five silver halide precipitation reactions (from table 6 ) and the thermodynamic quantities derived from them are given in table 7. The values of $\phi_{L}$ are taken from Parker [14], and the quantity, $q$ (demix), represents the correction for demixing the final solutions as described in section 5 . The values for the enthalpies of solution of the solute salts are taken from table 2 .

All of the values for $\Delta H^{\circ}$ pptn given in table 7 are in good agreement with those obtained from EMF measurements (see table 1). Our mean value for the chloride reactions, $-65.724 \mathrm{~kJ} \cdot \mathrm{mol}^{-1}$, is in good agreement with the value of Lange and Fuoss; for the bromide reactions our mean value, $-84.826 \mathrm{~kJ} \cdot \mathrm{mol}^{-1}$, agrees with those of Gellner and Skinner, and Berthelot; and for the iodide reaction our value, -111.125 $\mathrm{kJ} \cdot \mathrm{mol}^{-1}$ agrees best with that of Berthelot's first work.

\section{Gibbs Energies of Precipitation of the Silver Halides}

The available solubility data on the silver halides are presented in table 8 as the common logarithm of the solubility product. We have also calculated the values of $\log K_{s}$ for each silver halide from the appropriate values of the standard electrode potentials for 
TABLE 7. Data used in the calculation of the entropy of the aqueous silver ion from the enthalpies of the five silver halide precipitation reactions All values are at $298.15 \mathrm{~K}$

\begin{tabular}{|c|c|c|c|c|c|}
\hline Reaction & $\begin{array}{c}\mathrm{I} \\
\mathrm{KCl}(\mathrm{c}) \text { in } \\
\mathrm{AgNO}_{3}(\mathrm{aq})\end{array}$ & $\begin{array}{c}\mathrm{II} \\
\mathrm{AgNO}_{3}(\mathrm{c}) \\
\text { in } \mathrm{KCl}_{(\mathrm{aq})}\end{array}$ & $\begin{array}{c}\text { III } \\
\mathrm{KBr}_{\mathrm{KgNO}}(\mathrm{c}) \text { in } \\
\mathrm{AgN}_{3}(\mathrm{aq})\end{array}$ & $\begin{array}{c}\mathrm{IV} \\
\mathrm{AgNO}_{3}(\mathrm{c}) \\
\text { in } \mathrm{KBr}(\mathrm{aq})\end{array}$ & $\begin{array}{l}\mathrm{V} \\
\mathrm{AgNO}_{3}(\mathrm{c}) \\
\text { in } \mathrm{KI}(\mathrm{aq})\end{array}$ \\
\hline $\begin{array}{l}\Delta H r, \mathrm{~kJ} \cdot \mathrm{mol}^{-1} \\
q(\text { demix }), \mathrm{kJ} \cdot \mathrm{mol}^{-1} \\
\phi_{L}(\text { solvent }), \mathrm{kJ} \cdot \mathrm{mol}^{-1} \\
-\phi_{L}\left(\mathrm{KNO}_{3}\right), \mathrm{kJ} \cdot \mathrm{mol}^{-1} \\
\Delta H^{\circ}, \mathrm{kJ} \cdot \mathrm{mol}^{-1}\end{array}$ & $\begin{array}{r}-48.588 \\
+0.010 \\
-0.238 \\
+0.356 \\
-48.460\end{array}$ & $\begin{array}{r}-43.540 \\
+0.335 \\
+0.163 \\
-43.042\end{array}$ & $\begin{array}{r}-65.168 \\
+0.008 \\
-0.238 \\
+0.356 \\
-65.042\end{array}$ & $\begin{array}{r}-62.553 \\
+0.280 \\
+0.163 \\
-62.110\end{array}$ & $\begin{array}{r}-88.773 \\
+\overline{0} \\
+0.209 \\
-88.397\end{array}$ \\
\hline $\begin{array}{l}\Delta H^{\circ}(\infty)(\text { solute }), \mathrm{kJ} \cdot \mathrm{mol}^{-1} \\
\Delta H^{\circ} \text { pptn }, \mathrm{kJ} \cdot \mathrm{mol}^{-1}\end{array}$ & $\begin{array}{r}17.218 \\
-65.678\end{array}$ & $\begin{array}{r}22.727 \\
-65.769\end{array}$ & $\begin{array}{r}19.772 \\
-84.814\end{array}$ & $\begin{array}{r}22.727 \\
-84.837\end{array}$ & $\begin{array}{r}22.727 \\
-111.124\end{array}$ \\
\hline$\Delta G^{\circ}, \mathrm{kJ} \cdot \mathrm{mol}^{-1}$ & -55.652 & -55.652 & -70.206 & -70.206 & -91.827 \\
\hline$\Delta S^{\circ} p p t n, \mathrm{~J} \cdot \mathrm{mol}^{-1} \cdot \mathrm{K}^{-1}$ & -33.63 & -33.93 & -49.00 & -49.07 & -64.72 \\
\hline $\begin{array}{l}S^{\circ}[\mathrm{AgX}(\mathrm{c})], \mathrm{J} \cdot \mathrm{mol}^{-1} \cdot \mathrm{K}^{-1} \\
S^{\circ}[\mathrm{X}-(\mathrm{aq})], \mathrm{J} \cdot \mathrm{mol}^{-1} \cdot \mathrm{K}^{-1} \\
S^{\circ}\left[\mathrm{Ag}^{+}(\mathrm{aq})\right], \mathrm{J} \cdot \mathrm{mol}^{-1} \cdot \mathrm{K}^{-1}\end{array}$ & $\begin{array}{l}96.36 \\
56.73 \\
73.26\end{array}$ & $\begin{array}{l}96.36 \\
56.73 \\
73.56\end{array}$ & $\begin{array}{r}107.11 \\
82.84 \\
73.27\end{array}$ & $\begin{array}{r}107.11 \\
82.84 \\
73.34\end{array}$ & $\begin{array}{r}115.48 \\
106.70 \\
73.50\end{array}$ \\
\hline
\end{tabular}

TABLE 8. Selection of $\Delta \mathrm{G}^{\circ}$ of the precipitation reaction

All values are at $298.15 \mathrm{~K}$.

\begin{tabular}{|c|c|c|}
\hline Author & $\log K_{s}$ & Reference \\
\hline 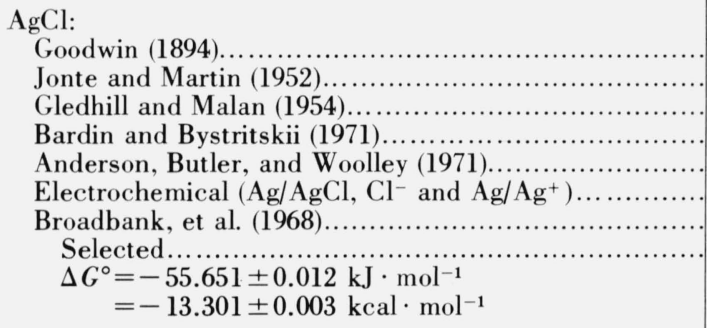 & $\begin{array}{l}-9.865 \\
-9.752 \\
-9.748 \\
-9.765 \\
-9.75 \\
-9.752 \\
-9.755 \\
-9.750\end{array}$ & $\begin{array}{l}{[28]} \\
{[29]} \\
{[13]} \\
{[30]} \\
{[31]}\end{array}$ \\
\hline 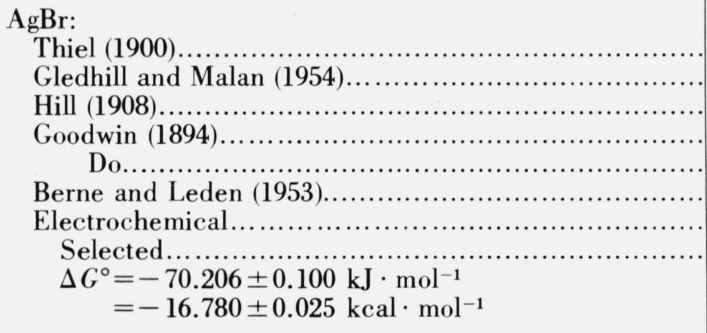 & $\begin{array}{l}-12.18 \\
-12.204 \\
-12.270 \\
-12.43 \\
-12.38 \\
-12.34 \\
-12.309 \\
-12.300\end{array}$ & $\begin{array}{l}{[33]} \\
{[13]} \\
{[34]} \\
{[28]} \\
\\
{[35]}\end{array}$ \\
\hline 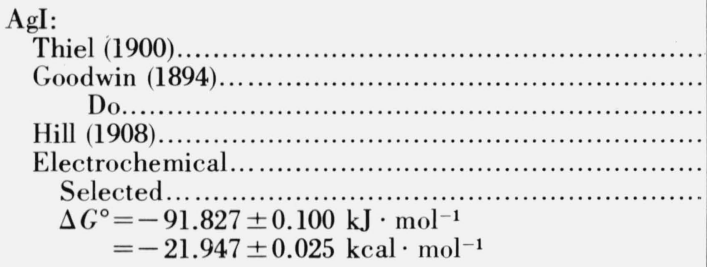 & $\begin{array}{l}-15.958 \\
-16.11 \\
-16.01 \\
-15.978 \\
-16.088 \\
-16.088\end{array}$ & $\begin{array}{l}{[33]} \\
{[28]}\end{array}$ \\
\hline
\end{tabular}

the $\mathrm{Ag} / \mathrm{Ag}^{+}(\mathrm{aq})$ and the $\mathrm{Ag} / \mathrm{AgX}(\mathrm{c}), \mathrm{X}^{-}(\mathrm{aq})$ electrodes $[1,4]$. These values are listed as "Electrochemical." The activity coefficients were taken as unity in all cases. The standard Gibbs energy of precipitation at $298.15 \mathrm{~K}$ is then

$$
\begin{aligned}
\Delta G^{\circ}=R T \ln K_{s} & =5.7079 \log K_{s}, \mathrm{~kJ} \cdot \mathrm{mol}^{-1} \\
& =1.36422 \log K_{s}, \mathrm{kcal} \cdot \mathrm{mol}^{-1} .
\end{aligned}
$$

\section{Entropy of the Aqueous Silver Ion}

The calculation of the entropy of precipitation of the silver halides is summarized in table $7 . \Delta S^{\circ}$ pptn $=\left(\Delta H^{\circ}\right.$ pptn $\left.-\Delta G^{\circ}\right) / T$. The entropies of the silver halide salts were calculated by graphical reintegration of the corresponding heat capacity data $[36,37]$; the 
entropies of the aqueous halide ions are the recommended CODATA values [38].

We have also calculated a value for the entropy of the silver ion from the data on $\mathrm{AgNO}_{3}(\mathrm{aq})$, using the CODATA preliminary value for the nitrate ion [39]. The solubility, 15.01 molal at $298.15 \mathrm{~K}$, was taken from the measurements of Skarulis and Ricci [40]; the activity coefficient at saturation was calculated to be $0.082[41,42]$. Combining these data with our selected best value of the enthalpy of solution we obtain

$$
\begin{aligned}
& \mathrm{AgNO}_{3}(\mathrm{c}) \rightarrow \mathrm{Ag}^{+}(\mathrm{aq})+\mathrm{NO}_{3}^{-}(\mathrm{aq}) \\
& \Delta G^{\circ}=-1.029 \pm 0.040 \mathrm{~kJ} \cdot \mathrm{mol}^{-1} \\
& =-0.246 \pm 0.010 \mathrm{kcal} \cdot \mathrm{mol}^{-1} \\
& \Delta H^{\circ}(\infty)=22.730 \pm 0.42 \mathrm{~kJ} \cdot \mathrm{mol}^{-1} \\
& =5.433 \pm 0.010 \mathrm{kcal} \cdot \mathrm{mol}^{-1} \\
& \Delta S^{\circ}=79.69 \mathrm{~J} \cdot \mathrm{mol}^{-1} \cdot \mathrm{K}^{-1} \\
& =19.05 \mathrm{cal} \cdot \mathrm{mol}^{-1} \cdot \mathrm{K}^{-1} \text {. }
\end{aligned}
$$

The entropy of $\mathrm{AgNO}_{3}(\mathrm{c}), 140.92 \pm 0.63 \mathrm{~J} \cdot \mathrm{mol}^{-1} \cdot \mathrm{K}^{-1}$ $\left(33.68 \pm 0.15 \mathrm{cal} \cdot \mathrm{mol}^{-1} \cdot \mathrm{K}^{-1}\right)$, was measured by Smith, Brown, and Pitzer [22], and the CODATA value for $\mathrm{NO}_{3}^{-}(\mathrm{aq})=146.94 \mathrm{~J} \cdot \mathrm{mol}^{-1} \cdot \mathrm{K}^{-1}(35.12 \mathrm{cal} \cdot$ $\left.\mathrm{mol}^{-1} \cdot \mathrm{K}^{-1}\right)$. Hence, we obtain for the $\mathrm{Ag}^{+}(\mathrm{aq})$ from $\mathrm{AgNO}_{3}$

$$
\begin{aligned}
S^{\circ}(298.15 \mathrm{~K}) & =73.67 \mathrm{~J} \cdot \mathrm{mol}^{-1} \cdot \mathrm{K}^{-1} \\
& =17.61 \mathrm{cal} \cdot \mathrm{mol}^{-1} \cdot \mathrm{K}^{-1} .
\end{aligned}
$$

in excellent agreement with the values obtained from the halides.

We can also obtain a value for the entropy of $\mathrm{Ag}^{+}(\mathrm{aq})$ from our recalculation and reextrapolation of the data of Owen and Brinkley [4] for the silver electrode. We have fitted the values of $E^{\circ}$ in volts to a quadratic function of the temperature, obtaining the equation $(T$ in $\mathrm{K})$ :

$$
\begin{aligned}
E^{\circ}=-0.79910+9.930 \times 10^{-4}(T-298.15) & \\
+ & 4.05 \times 10^{-7}(T-298.15)^{2} .
\end{aligned}
$$

Thus, for the reaction

$$
\begin{aligned}
\operatorname{Ag}(\mathrm{c})+\mathrm{H}^{+}(\mathrm{aq}) \rightarrow \mathrm{Ag}^{+}(\mathrm{aq})+\frac{1}{2} \mathrm{H}_{2}(\mathrm{~g}) & \\
\Delta S^{\circ}(298.15 \mathrm{~K})=95.81 & \pm 0.13 \mathrm{~J} \cdot \mathrm{mol}^{-1} \cdot \mathrm{K}^{-1} \\
S^{\circ}\left[\mathrm{Ag}^{+}(\mathrm{aq})\right](298.15 \mathrm{~K}) & =73.08 \mathrm{~J} \cdot \mathrm{mol}^{-1} \cdot \mathrm{K}^{-1} \\
& =17.47 \mathrm{cal} \cdot \mathrm{mol}^{-1} \cdot \mathrm{K}^{-1}
\end{aligned}
$$

The entropies of $\mathrm{Ag}(\mathrm{c})$ and $\mathrm{H}_{2}(\mathrm{~g})$ are taken from [43] and [38] respectively.

Table 9 summarizes the values obtained in this paper for the entropy of $\mathrm{Ag}^{+}$(aq) with estimated overall uncertainties. We have assigned a smaller weight to the value obtained from the EMF measurements because of the uncertainty in the temperature coefficient, and to the value from AgI because of the relatively large uncertainty in the entropy of $\mathrm{AgI}(\mathrm{c})$ [37]. As a final mean value we have selected

$$
\begin{aligned}
S^{\circ}\left[\mathrm{Ag}^{+}(\mathrm{aq})\right](298.15 \mathrm{~K}) & =73.42 \pm 0.20 \mathrm{~J} \cdot \mathrm{mol}^{-1} \cdot \mathrm{K}^{-1} \\
& =17.55 \pm 0.05 \mathrm{cal} \cdot \mathrm{mol}^{-1} \cdot \mathrm{K}^{-1}
\end{aligned}
$$

This value is in almost exact agreement with the value, $17.54 \pm 0.15 \mathrm{cal} \cdot \mathrm{mol}^{-1} \cdot \mathrm{K}^{-1}$, obtained by Pitzer and Smith [44], based on the solution data on $\mathrm{Ag}_{2} \mathrm{O}$ (c) and on earlier measurements of the precipitation of AgCl. We believe the excellent concordance obtained in the various determinations listed in table 9 indicates that the silver halides encountered in the various calorimetric experiments are in the same thermodynamic states as those in the solubility measurements and in the electrochemical measurements. The effects of such factors as particle size or degree of crystallinity for these halides under ordinary conditions must be smaller than can be detected by our present calorimetric techniques.

TABLE 9. Selection of entropy of $\mathrm{Ag}^{+}$(aq)

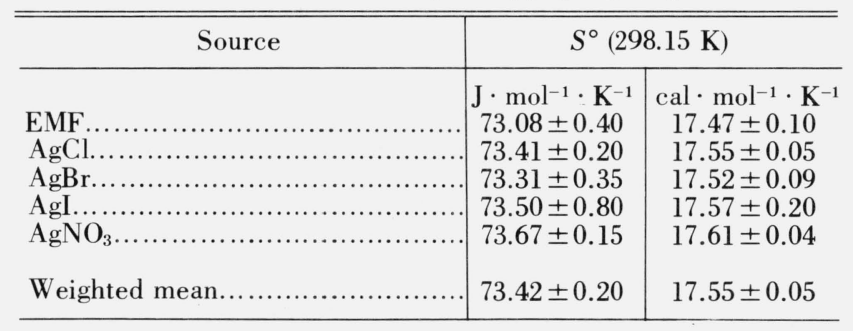

\section{References}

[1] Bates, R. G., and Bower, V. E., J. Res. Nat. Bur. Stand. (U.S.), 53, 283 (1954); Hetzer, H. B., Robinson, R. A., and Bates, R. G., J. Phys. Chem. 66, 1423 (1962); Hetzer, H. B., Robinson, R. A., and Bates, R. G., J. Phys. Chem. 68, 1929 (1964).

[2] Wagman, D. D., Evans, W. H., Parker, V. B., Halow, I., Bailey, S., and Schumm, R. H., Selected Values of Chemical Thermodynamic Properties, Nat. Bur. Stand. (U.S.), Tech. Note 270-3, et seq; Termicheski Constanty Veshchestv (Thermal Constants of Substances), Glushko, V. P., Ed., Academy of Sciences, U.S.S.R., Moscow.

[3] Harned, H. S., and Owen, B. B., The Physical Chemistry of Electrolytic Solutions, 3rd Edition, ACS Monograph 137 (Reinhold Publ. Co., New York, 1958) p. 428.

[4] Owen, B. B., and Brinkley, S. R., Jr., J. Am. Chem. Soc. 60, 2233 (1938).

[5] Lange, E., and Fuoss, R., Z. physik. Chem. 125, 431 (1927).

[6] Thomsen, J., Thermochemical Investigations III, Barth, J., Leipsig (1883).

[7] Berthelot, M., Compt. rend. 93,870 (1881).

[8] Gellner, O. H., and Skinner, H. A., J. Chem. Soc. 1949, 1145.

[9] Roth, W. A., Z. Elektrochem. 50, 107 (1944).

[10] Berthelot, M., Ann. chim. phys. [5] 4,160 (1875).

[11] Lange, E., and Shibata, Z., Z. physik. Chem. A149, 465 (1930).

[12] Yatsimirskii, K. B., and Skutov, A. A., Zhur. Fiz. Khim. 28, 30 (1954).

[13] Gledhill, J. A., and Malan, G. M., Trans. Faraday Soc. 50, 126 (1954). 
[14] Parker, V. B., Thermal Properties of Aqueous Uni-univalent Electrolytes, Nat. Stand. Ref. Data Ser. Nat. Bur. Stand. (U.S.), 2, 66 pages (April 1965).

[15] Prosen, E. J., and Kilday, M. V., J. Res. Nat. Bur. Stand. (U.S.), 77A, 179 (1973).

[16] Commission on Atomic Weights, Pure and Applied Chem. 21,91 (1970).

[17] International Critical Tables (McGraw Hill Book Co., Inc New York), (a) Vol. I, 124, 154 (1926); (b) Vol. III, 67, 87-88 (1928).

[18] Prosen, E. J., and Kilday, M. V., J. Res. Nat. Bur. Stand. (U.S.) 77A, 581 (1973).

[19] Tsvetkov, V. G., and Rabinovich, I. B. Zhur. Fiz. Khim. 43 , 1213 (1969).

[20] Lewis, G. N., and Randall, M., Thermodynamics revised by Pitzer, K. S., and Brewer, L. (McGraw Hill Book Co., Inc. New York, 1961), page 642.

[21] Lange, E., and Martin, W., Z. physik. Chem. A180,233 (1937).

[22] Smith, W. V., Brown, O. L. I., and Pitzer, K. S., J. Am. Chem. Soc. 59, 1213 (1937).

[23] Graham, R. L., and Hepler, L. G., J. Am. Chem. Soc. 80, 3538 (1958).

[24] Shidlovskii, A. A., and Voskresenskii, A. A., Zhur. Fiz. Khim. 3 7, 2062 (1963).

[25] Karapet'yants, M. Kh., Vlasenko, K. K., and Solov'eva, S. G.. Russ. J. Phys. Chem. 44, 305 (1970).

[26] Wu, Y. C., Smith, M. B., and Young, T. F., J. Phys. Chem. 69, 1868 (1965).

[27] Wood, R. H., and Smith, R. W., J. Phys. Chem. 69, 2974 (1965).

[28] Goodwin, H. M., Z. physik. Chem. 13, 577 (1894).

[29] Jonte, J. H., and Martin, D. S., J. Am. Chem. Soc. 74, 2052 (1952).
[30] Bardin, V. V., and Bystritskii, A. L., Zhur. Priklad. Khim. 44, 1159 (1971).

[31] Anderson, K. P., Butler, E. A., Woolley, E. M., J. Phys. Chem. 75, 93 (1971).

[32] Broadbank, R. W. C., Dhabanandana, S., and Morcum, K. W., J. Chem. Soc. (A) 1968, 213.

[33] Thiel, A., Z. anorg. Chem. 24, 1 (1900).

[34] Hill, A. E., J. Am. Chem. Soc. 30, 68 (1908).

[35] Berne, E., and Leden, I., Z. Naturforsch. 8a, 719 (1953).

[36] Eastman, E. D., and Milner, R. T., J. Chem. Phys. 1, 444 (1933).

[37] Pitzer, K. S., J. Am. Chem. Soc. 63, 516 (1941).

[38] CODATA Bulletin Number 5, ICSU Committee on Data for Science and Technology (December 1971).

[39] CODATA Bulletin Number 7, ICSU Committee on Data for Science and Technology (August 1972).

[40] Skarulis, J. A., and Ricci, J. E., J. Am. Chem. Soc. 63, 3429 (1941).

[41] Robinson, R. A., and Tait, D. A., Trans. Faraday. Soc. 37, 569 (1941).

[42] Kangro, W., and Groeneveld, A., Z. physik. Chem. [NF] 32, 110 (1962).

[43] Furukawa, G. T., Saba, W. G., and Reilly, M. L., Nat. Stand. Ref. Data Ser. Nat. Bur. Stand. (U.S.), 18, 49 pages (April 1968).

[44] Pitzer, K. S., and Smith, W. V., J. Am. Chem. Soc. 59, 2633 (1937).

[45] Nat. Bur. Stand. (U.S.) Tech. News Bull. 47 No. 10, 175 (1963).

(Paper 77A5-784) 